\title{
A Rare Cause of ST-Segment Elevation Myocardial Infarction in COVID-19: MINOCA Syndrome
}

\author{
COVID-19'da ST Segment Yükseklikli Miyokart Infarktüsünün \\ Nadir Bir Nedeni: MINOCA Sendromu
}

Serkan Emre EROGLU ๑, Enis ADEMOGLU ๑, Samet BAYRAM ๑, Gökhan AKSEL ๑

Ethics Committee Approval: Not applicable.

Conflict of interest: The authors declare that they have no conflict of interest.

Funding: None.

Informed Consent: Informed consent was taken.

\begin{abstract}
Myocardial infarction with nonobstructive coronary arteries (MINOCA) is defined as having a stenosis of less than $50 \%$ or no stenosis in coronary angiography in a patient diagnosed with myocardial infarction.

Because of its thrombogenic predisposition in COVID-19, the diagnosis of MINOCA syndrome is rarely thought in the patients with ST-segment elevation myocardial Infarction on electrocardiogram. In this case report, we discuss a 47-year-old male patient diagnosed with MINOCA who was followed up with respiratory failure due to COVID-19 viral pneumonia in intensive care unit. His 12-lead electrocardiogram showed "inferior STEMI". A 30-40\% stenosis was also shown in the midportion of left anterior descending artery in emergency coronary angiography. The patient had a normal computed tomographic pulmonary angiography and was discharged with a full recovery.

MINOCA may be triggered by hyperinflammation or various processes due to COVID-19. To explain these processes associated with MINOCA syndrome, further clinical trials are needed.
\end{abstract}

Keywords: MINOCA, COVID-19, STEMI

öz

Non-obstrüktif Koroner Arterlerle birlikte Miyokart Infarktüsü (MINOCA), miyokard infarktüsü teşhisi konulan bir hastada koroner anjiyografide darlığın \%50'den az olması veya dar olmaması olarak tanımlanır.

COVID-19'daki büyük trombojenik yatkınlığı nedeniyle, elektrokardiyogram'da ST-elevasyonlu miyokard infarktüsü görülen hastalarda MINOCA sendromu tanısı nadiren düşünülür. Bu vaka sunumunda, yoğun bakım ünitesi'nde, COVID-19 viral pnömonisine bağlı solunum yetmezliği ile takip eden MINOCA tanısı almış 47 yaşında bir erkek hastayı tartışıyoruz. Hastanın 12derivasyonlu elektrokardiyografisinde "inferiyor STEMI" vard. Acil koroner anjiyografide de sol ön inen arter orta kısmında \%30-40 darlık gösterildi. Bilgisayarlı tomografik pulmoner anjiyografisi normal olan hasta iyileşerek evine taburcu edildi.

MINOCA, COVID-19'a bağlı olarak hiperinflamasyon veya çeşitli süreçlerle tetiklenebilir. MINO$C A$ sendromuyla ilişkili bu süreçleri açıklamak için daha fazla klinik denemeye ihtiyaç vardır.

Anahtar kelimeler: MINOCA, COVID-19, STEMI
Received: 16 January 2021

Accepted: 28 February 2021

Online First: 26 March 2021

Corresponding Author: S.E. Eroglu ORCID: 0000-0002-3183-3713

Health Sciences University, Umraniye Research and Training

Hospital, Department of Emergency Medicine, Istanbul, Turkey

drseroglu@gmail.com

E. Ademoglu ORCID: 0000-0002-6330-666X S. Bayram ORCID: 0000-0003-2647-3386

G. Aksel ORCID: 0000-0002-5580-3201 Health Sciences University, Umraniye Research and Training Hospital, Department of Emergency Medicine, Istanbul, Turkey 


\section{INTRODUCTION}

Although defined as a respiratory disease and an inflammatory syndrome, COVID-19 increases the risk of venous and arterial thromboembolic events ${ }^{1}$. As reported in the literature, thromboembolic event rates are changing in the range of $23-42 \%$ in COVID-19 patients followed in Intensive Care Units (ICUs) ${ }^{2-5}$. The virus, which binds to ACE2 receptors in organs such as lungs and heart, is thought to trigger thrombotic mechanisms along with the inflammatory response. Pulmonary embolism is more common as a thrombotic complication, but also the cardiac involvement of COVID-19 should not be ignored $^{6}$. Although entities such as myopericarditis are primarily considered as inflammatory complications in COVID-19 patients, acute coronary syndrome may also be seen in these patients due to the tendency to thrombosis caused by the disease ${ }^{7}$.

According to the fourth universal definition of Myocardial Infarction the term myocardial infarction with nonobstructive coronary arteries (MINOCA) was newly defined in the literature as having a stenosis of less than $50 \%$ or no stenosis in coronary angiography in a patient diagnosed with $\mathrm{MI}^{8}$. Inflammation, hypoxia and thrombotic environment found in COVID-19 patients may predispose to MINOCA, apart from classical atherosclerotic coronary artery disease.

In this case report, it was aimed to present a male patient with MINOCA syndrome that was clinically diagnosed with STEMI during his hospitalization in the COVID-19 ICU and no significant stenosis was found in his coronary angiography.

The patient provided written informed consent and our medical management was conducted in accordance with protection of human subjects and the provisions of the Declaration of Helsinki.

\section{CASE PRESENTATION}

A 47-year-old male patient whose diagnosis of COVID-19 confirmed by reverse transcriptase polymerase chain reaction (nasal swab) testing was hospitalized with a six-days history of shortness of breath. He described typical anginal pain on his second day of hospitalization in COVID-19 ICU. He never smoked in and his past medical history was only significant for hypertension. He was on the tenth day of his COVID-19 diagnosis and he had fever with improvement on acetaminophen and six days of non-productive cough and dsypnea. He had been admitted to ICU due to progressive oxygen desaturation on fourth day of his hospitalization. Prior to ICU admission, thorax CT revealed diffuse bilateral infiltrates, ground glass opacities, crazy paving with thickened interlobular septa, and consolidation in lower lobes. Before onset of his angina symptoms, the patient was being treated in ICU with daily doses of 2x4000 IU sc, enoxaparin sodyum, 1x80 mg prednisolon iv, $1 \times 400 \mathrm{mg}$ moxifloksasin iv, 1x5 mg amlodipin po. It was known that he had been treated with favirapiravir for 10 days $(1600 \mathrm{mg}$ orally twice daily for one day followed by $600 \mathrm{mg}$ orally twice daily for nine days), and $1 \times 2$ gr ceftriaxone iv for 6 days before he was admitted to ICU. During his anginal pain, the vital parameters of the patient followed up with the support of high-flow nasal oxygen (HFNO) revealed blood pressure of $135 / 68 \mathrm{mmHg}$, heart rate of $73 \mathrm{bpm}$, oxygen saturation of $88-93 \%(60 \mathrm{~L} / \mathrm{min}$ flow rate with $90 \% \mathrm{FiO}_{2}$ with $\mathrm{HFNO}$ ), and body temperature of $36.7^{\circ} \mathrm{C}$. His cardiac examination at that time was also within normal limits. However, a 12-lead electrocardiogram (ECG) showed the inferior STEMI (Figure 1). The patient was diagnosed with STEMI was started on $300 \mathrm{mg}$ po acetylsalicylic acid, $180 \mathrm{mg}$ po ticagrelor, and 4000 IU IV heparin treatment. Patient's cardiac symptoms decreased and finally disappeared within 30 minutes. Emergency coronary angiography showed $30-40 \%$ stenosis in the midportion of the left anterior descending artery. In addition 

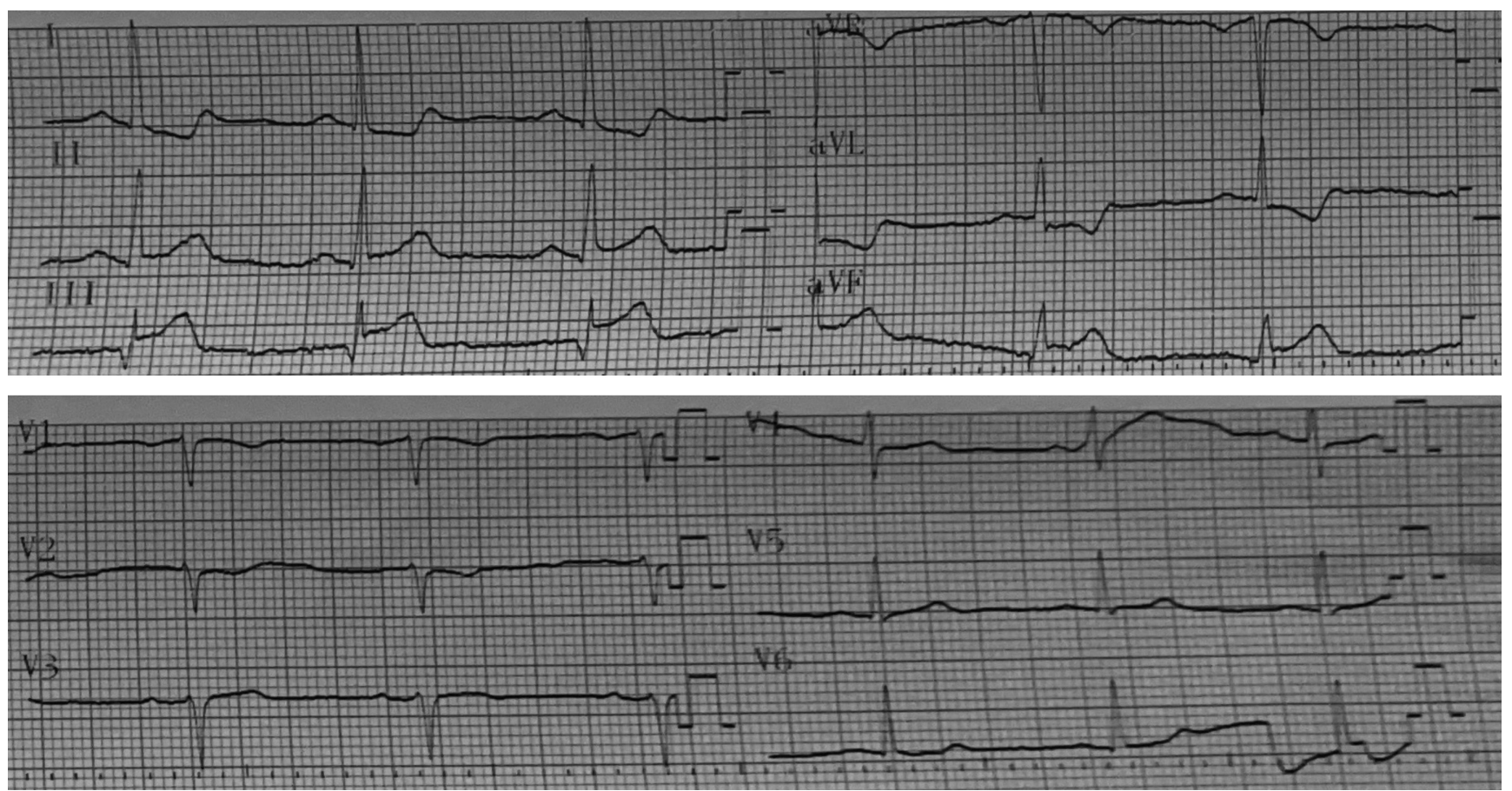

Figure 1. DII, DIII and aVF leads show $1 \mathrm{~mm}$ ST elevation, and 0.5-1 mm ST depression in DI and aVL leads.

to this, the left main coronary artery, left circumflex artery and right coronary artery were observedly normal (Figure 2). ST segment elevation regressed in the ECG of the patient, who had no more ischemic cardiac symptoms after the intervention (Figure 3).

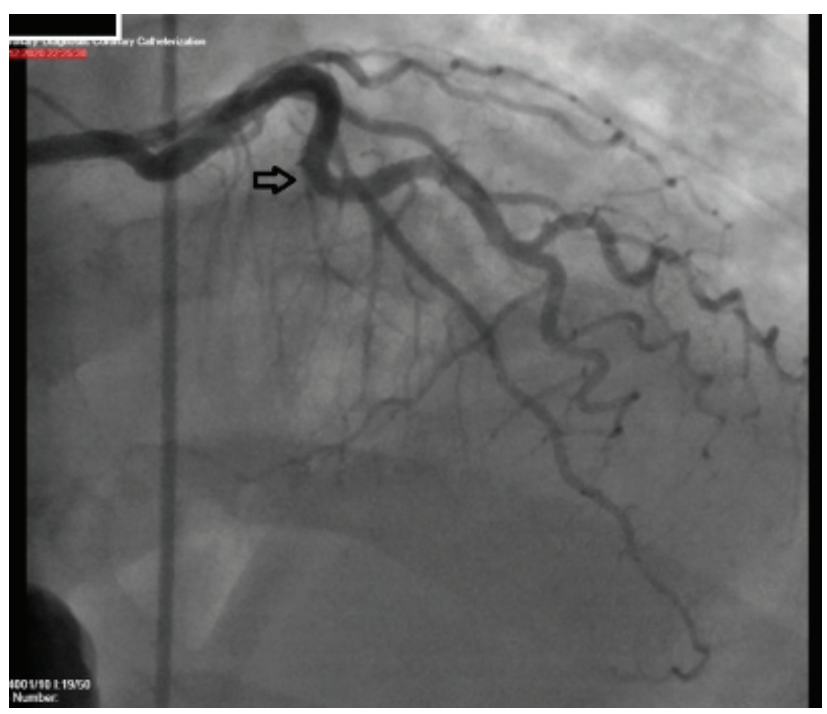

Figure 2. Emergency coronary angiography of the patient shows $30-40 \%$ stenosis in the left anterior descending artery.
The high sensitivity troponin (hs-cTnI) value obtained at the time he had symptoms, was detected as $0.012 \mathrm{ng} / \mathrm{mL}(<0.0262 \mathrm{ng} / \mathrm{mL})$, and the troponin value measured after the procedure was $0.056 \mathrm{ng} / \mathrm{mL}$. Kidney and liver function tests were within normal limits. However increased levels of d-dimer $(520 \mathrm{ng} / \mathrm{mL} ; \mathrm{N}<500 \mathrm{ng} / \mathrm{mL}$ ), fibrinogen (589 mg/dL; $\mathrm{N}$ : 200-400 mg/dL), ferritin (1693 ng/ mL; N:22-275 ng/mL), lactate dehydrogenase (466 U/L; N:125-220 U/L), and C-reactive protein $(4.1 \mathrm{mg} / \mathrm{dL}: \mathrm{N}:<0.5 \mathrm{mg} / \mathrm{dL})$ were detected, while pro-brain natriuretic peptide level was $20 \mathrm{pg} / \mathrm{mL}$ ( $\mathrm{N}$ : $<100 \mathrm{pg} / \mathrm{mL}$ ). Computed tomographic pulmonary angiography (CTPA) did not reveal any evidence of pulmonary embolism. MINOCA was considered in the patient whose ECG findings showed inferior STEMI at the time of typical angina pain while his coronary angiography did not reveal any sign of significant stenosis.

Cardiogoniometry (a non-invasive medical tool worked with spatiotemporal vectocardiographic advancement), was performed after 24 hours of 

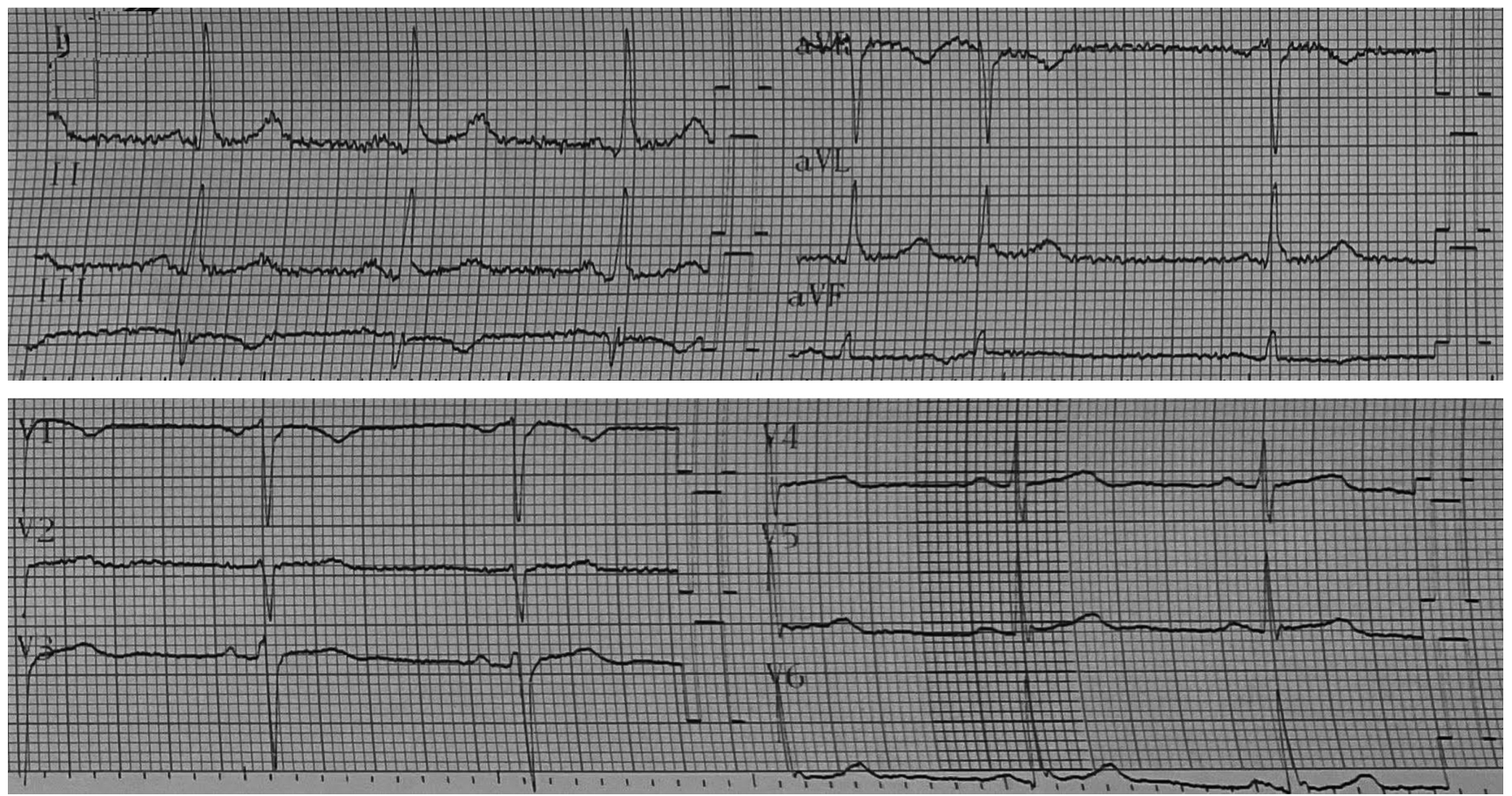

Figure 3. It is seen that the ST elevation and depressions regress relative to the patient's first ECG.

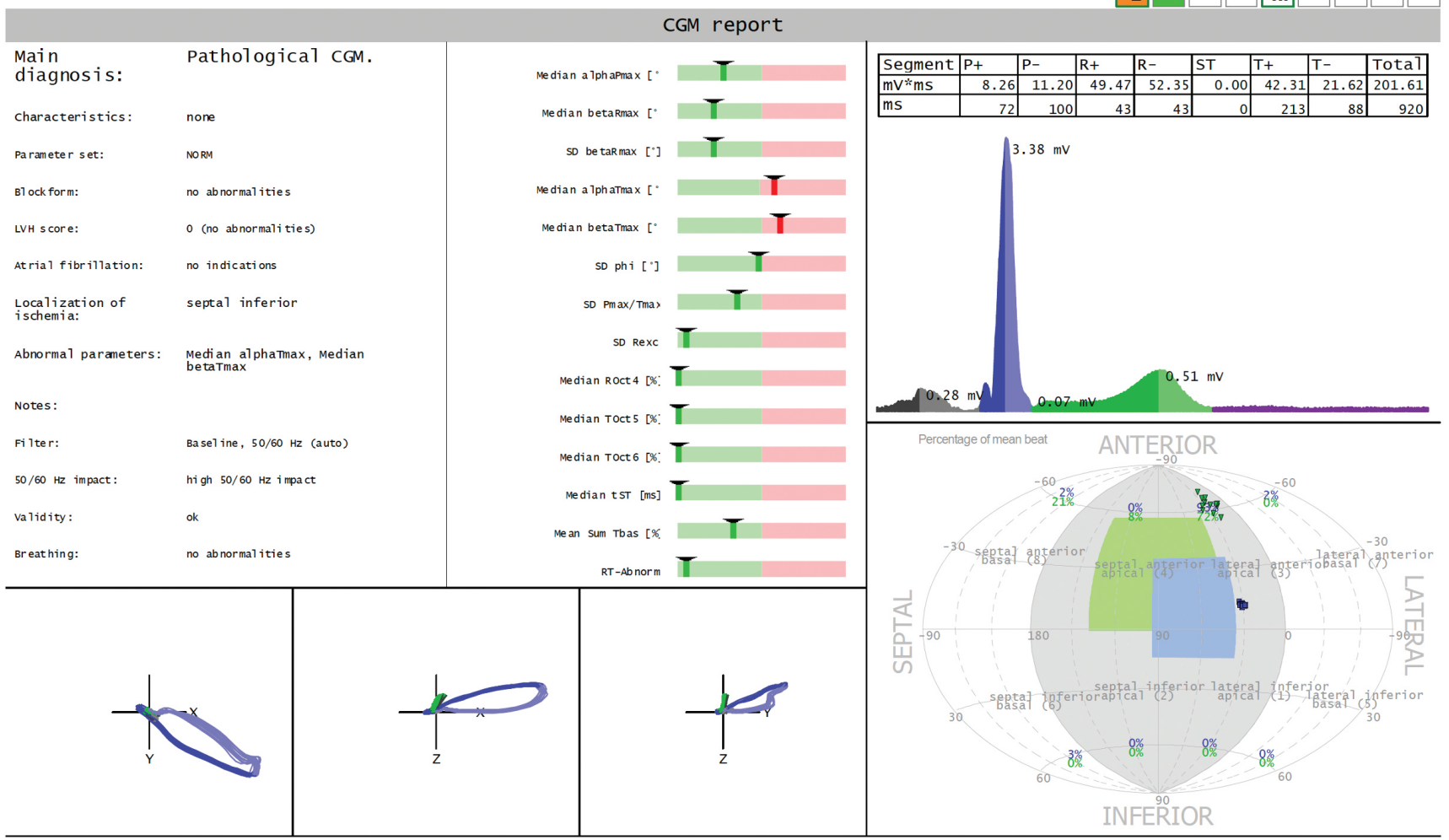

Figure 4. 3D ECG /Cardiogoniometry performed to the patient shows septal inferior myocardial ischemia. 
the pain, it revealed septal inferior myocardial ischemia (Figure 4), and supported our diagnosis. After starting medical treatment of the acute coronary syndrome and viral pneumonia stage of the disease, the patient was followed up with progressive clinical and hemodynamic improvement. He was transferred to the normal medical ward on the fifth day in the ICU, and he was discharged on the eleventh day of his hospitalization in a healthy state.

\section{DISCUSSION}

The binding of COVID-19 virus to ACE2 receptors in endothelial cells with surface glycoproteins activates the thrombotic process with the proinflammatory response in the endothelium. This thrombotic process, associated with activation of leukocyte, thrombocyte and endothelial cells, and complements, secretion of multiple cytokines, and ultimately, an excessive increase in thrombin production, causes not only venous but also microvascular and arterial thrombosis ${ }^{6}$. Helms et al. ${ }^{5}$ confirmed that in comparison with nonCOVID-19 ARDS patients, COVID-19 ARDS patients significantly more often developed trombotic complications, mainly pulmonary embolisms (11.7 vs. $2.1 \%, p<0.008$ ).

It was reported that different thrombotic patterns such as stroke and acute coronary syndrome may occur with similar functioning mechanisms via the ACE2 enzyme, which is also found in organs such as the heart, kidney, and vascular endothelium ${ }^{7,9}$. In a recent study ${ }^{10}$, the incidence of acute coronary syndrome in hospitalized COVID-19 patients was reported as $1.1 \%$.

Although it is thought that many mechanisms such as hyperinflammation, cytokine storm, thrombosis, and hypoxia may occur together in the cardiac involvement of COVID-19, the increased thrombotic environment may induce MINOCA in COVID-19 patients with acute coronary syndrome ${ }^{11}$. In a prospective study compar- ing two different cohorts with and without COVID-19 in STEMI patients, coronary angiography was found to be compatible with MINOCA in $54 \%$ of patients in the COVID-19 group ${ }^{12}$. In our patient, whose coronary angiography did not have significant stenosis and CTPA could not reveal any evidence of pulmonary embolism, it was thought that the reason of typical anginal pain with ST-segment elevation in the inferior leads on the ECG was MINOCA triggered by hyperinflammation and thrombotic processes due to COVID-19.

The pathogenetic mechanisms such as coronary plaque rupture, coronary vasospasm, thrombosis, type $2 \mathrm{MI}$, coronary dissection, cardiomyopathy, and myocarditis are included in the etiology of MINOCA. In addition to this, it has been emphasized that clinical conditions such as coronary vasospasm, hypoxia that cause type $2 \mathrm{MI}$ and coexistence of thrombosis mechanisms are more likely in these patients ${ }^{13}$. It cannot be denied that the situation created by the mechanisms of susceptibility to thrombosis, inflammation and accompanying hypoxia in COVID-19 patients followed in the ICU coincides with the pathophysiology of MINOCA. In some studies even fluoroquinolones were associated with a risk of cardiac events ${ }^{14}$. So that, we are aware that many factors, including the use of fluoroquinolone, can cause STEMI in our patient. As such, particular attention must be paid to such complications in patients predisposed to the development thrombotic complications by monitoring thrombotic and inflammatory parameters such as D-dimer, LDH, ferritin, fibrinogen and CRP, especially in populations at increased risk.

\section{Limitations}

In the differential diagnosis of MINOCA, pulmonary and cardiac causes such as pulmonary embolism, myopericarditis, cardiomyopathy, and systemic causes such as sepsis and renal disorders that may result in troponin elevation and ECG changes ${ }^{15}$ should be excluded. Therefore, 
one of the recommended cardiac tests is cardiac magnetic resonance imaging (MRI). As a limitation, cardiac MRI could not be performed on the patient in our case. However myocarditis and not already considered clinically significant as the patient had typically short-lasting anginal pain, and the ST elevation on the ECG in the inferior leads was accordant with perfusion of the particular perivascular area.

\section{CONCLUSION}

Hypoxia and thrombotic environment that coexist in COVID-19 patients can predispose them to acute coronary syndrome as well as thrombotic complications such as pulmonary embolism and stroke.

Overall, large cohort clinical trial is needed for further exploration of MINOCA.

\section{REFERENCES}

1. Ali MAM, Spinler SA. COVID-19 and thrombosis: From bench to bedside. Trends Cardiovasc Med. 2020;31:14360. [CrossRef]

2. Cui S, Chen S, Li X, Liu S, Wang F. Prevalence of venous thromboembolism in patients with severe novel coronavirus pneumonia. J Thromb Haemost. 2020;18:1421-4. [CrossRef]

3. Hippensteel JA, Burnham EL, Jolley SE. Prevalence of venous thromboembolism in critically ill patients with COVID-19. Br J Haematol. 2020;190:e134-7. [CrossRef]

4. Klok FA, Kruip MJHA, van der Meer NJM, et al. Confirmation of the high cumulative incidence of thrombotic complications in critically ill ICU patients with
COVID-19: an updated analysis. Thromb Res. 2020;191:148-50. [CrossRef]

5. Helms J, Tacquard C, Severac F, et al. High risk of thrombosis in patients with severe SARS-CoV-2 infection: a multicenter prospective cohort study. Intens Care Med. 2020;46:1089-98. [CrossRef]

6. McFadyen JD, Stevens H, Peter K. The emerging threat of (micro) thrombosis in COVID-19 and its therapeutic implications. Circ Res. 2020;127:571-87. [CrossRef]

7. Abobaker A, Raba AA, Alzwi A. Extrapulmonary and atypical clinical presentations of COVID-19. J Med Virol. 2020;92:2458-64. [CrossRef]

8. Thygesen K, Alpert JS, Jaffe AS, et al. Fourth universal definition of myocardial infarction (2018). Circulation. 2018;138:e618-51. [CrossRef]

9. Bangalore S, Sharma A, Slotwiner A, et al. ST-segment elevation in patients with Covid-19 - a case series. N Engl J Med. 2020;382:2478-80. [CrossRef]

10. Lodigiani C, Iapichino G, Carenzo L, et al. Venous and arterial thromboembolic complications in COVID-19 patients admitted to an academic hospital in Milan, Italy. Thromb Res. 2020;191:9-14. [CrossRef]

11. Clerkin KJ, Fried JA, Raikhelkar J, et al. COVID-19 and cardiovascular disease. Circulation. 2020;141:1648-55. [CrossRef]

12. Popovic B, Varlot J, Metzdorf PA, Jeulin H, Goehringer F, Camenzind $\mathrm{E}$. Changes in characteristics and management among patients with ST-elevation myocardial infarction due to COVID-19 infection. Catheter Cardiovasc Interv. 2021;97:e319-26. [CrossRef]

13. Agewall S, Beltrame JF, Reynolds HR, et al. ESC working group position paper on myocardial infarction with nonobstructive coronary arteries. Eur Heart J. 2017;38:14353. [CrossRef]

14. Polgreen LA, Riedle BN, Cavanaugh JE, et al. Estimated cardiac risk associated with macrolides and fluoroquinolones decreases substantially when adjusting for patient characteristics and comorbidities. J Am Heart Assoc. 2018;7:e008074. [CrossRef]

15. Pustjens TFS, Appelman Y, Damman P, et al. Guidelines for the management of myocardial infarction/injury with non-obstructive coronary arteries (MINOCA): a position paper from the Dutch ACS working group. Neth Heart J. 2020;28:116-30. [CrossRef] 